\title{
Yeast from Epiphyte of Avocadoes to Control Colletotrichum gloesporioides Causing Antrachnose Disease
}

\author{
Anton Muhibuddin ${ }^{1)}$, Siti Fadilah ${ }^{1)}$, Antok Wahyu Sektiono ${ }^{1)}$, Umi Kulsum Nur Qomariyah ${ }^{1)}$, \\ Mazidatul Faizah ${ }^{2)}$, Ambar Susanti' ${ }^{2}$, Sri Nurhatika ${ }^{3)}$
${ }^{1}$ Departement of Pests and Plant Disease, Agriculture Faculty, Brawijaya University ${ }^{2}$ Agroecotechnology Program, Agriculture Faculty, University of KH. Abd. Wahab Hasbullah
${ }^{3}$ Biology Department, Faculty of Science, Institute of Techology $10^{\text {th }}$ Nopember Correspondence Author: antonmhb@gmail.com

\begin{abstract}
Anthracnose disease caused by Colletotrichum gloesporioides fungi is an important disease in avocado fruit during storage. An effective, cheap, and non poisoned control method were required during storage to minimize chemical pesticide residues. This observation was aimed to select yeast with antagonistic ability from avocado epiphyte. Selected yeasts then tested their antagonist ability versus Colletotrichum gloesporioides, the fungi causing antrachnose disease, in vitro. Based on visual observation, microscopically and macroscopically, known that there were 3 yeast species isolated from green-long avocado variety i.e.: Candida sp., Filobasidium sp., and Cryptococcus sp., and then from mega gagauan avocado variety i.e.: Pichia sp., Candida sp., Cryptococcus sp., and Metschnikowia sp. The most antagonist yeast was Cryptococcus sp, which isolated from greenlong avocado.
\end{abstract}

Keyword: Yeast, antagonist, storage, avocado, anthracnose 


\section{INTRODUCTION}

Yeast is one of antagonist microorganism with anti-microbial compounds poisoning others microorganism. Yeast found anywhere including in plant epiphyte. Compare to others microbes like bacteria and fungi, yeast more adaptable to dry, more resistant to sunshine, weather fluctuation and poor nutrition (El-Tarabily \& Sivasithamparam, 2006; Ivanesthi et al., 2016; Sari, et al., 2016).

Usually, avocado fruit was harvested in immature condition in order to long storage purpose. During storage process, the most important disease of avocado fruit is anthracnose caused by Colletotrichum gloesporioides fungi. The disease decrease fruit quality and quantity. The symptom of disease is brown-darkness patchy then fruit become rotten. Pathogens need only two days to show the symptom on fruit (Nelson, 2008).

The best choice to control the disease is non chemical control using yeast antagonist. Exploring yeasts from avocados and test its antagonist ability was our aim in this observation.

\section{MATERIALS AND METHODS}

\subsection{Microbes isolation and purification}

A pathogen fungus (C. Gloesporioides) was isolated from avocado which anthracnose symptoms. Avocado was washed with sterilized water, and then cut in size $1 \mathrm{~cm} \times 1 \mathrm{~cm}$. The avocado pieces then were soaked in $2 \% \mathrm{NaCl}$, then in $70 \%$ alcohol, and in sterilized water, respectively. Before grown on PDA medium, the pieces were dried in room temperature for minutes. The pieces on medium were incubated for a few days till grow the colonies. The colony then was grown to purify on new PDA medium till obtain a pure culture.

Yeasts were isolated from peel and flesh of two avocado varieties; mega gagauan and greenlong. $10 \mathrm{~g}$ peel and $10 \mathrm{~g}$ flesh samples weight were put in $90 \mathrm{ml}$ sterile water and be shaken at 120 $\mathrm{rpm}$ speed with $120 \mathrm{rpm}$ shaker for 24 hours. Immersion water then diluted at $10^{-3}, 10^{-4}$, and $10^{-5}$ dilution, respectively. $50 \mu \mathrm{l}$ dilution planted on Yeast Malt Agar (YMA) with a spread plate method and incubate for 2-3 days at 25-30 ${ }^{\circ} \mathrm{C}$ (Assis \& Mariano, 1999).

\subsection{Identification and Stock Culture}

Fungi isolate was identified macroscopically based on colour and texture of colony. While microscopically identification based on hyphae and conidia shape, conidia size, as well as other specific characteristics. Both identification according to "the Key of Fungi Identification" (Barnett \& Hunter, 1998) and "The yeasts a Taxonomy Study" (Kurtzman \& Fell, 1998).

Yeast identification macroscopically based on shape, color, texture, colony edge and colony elevation. While microscopically identification based on cell shape, budding patterns and pseudohyphae existence.

Each of yeast and fungi colonies inoculated on PDA slant medium in a test tube for a stock culture. Yeast was inoculated with streak method while fungi with the straight streak method. The stock cultures then incubated at $28^{\circ} \mathrm{C}$ temperature for a few days. The stock culture then has been stored in at $4^{\circ} \mathrm{C}$ temperature refrigerator (Yarrow, 1998).

\subsection{The Diversity Index Measurement}

According to Brower and Zar (1977); Ludwig dan Reynold (1988) the diversity of index measurement be calculated using formula:

$$
\mathrm{H}^{\prime}=\sum_{i=1}^{s}\left(\frac{n i}{N}\right) \ln \left(\frac{n i}{N}\right)
$$

ISSN Print $\quad: 1979-7141$

ISSN Online : 2541-1942 
Description:

$\mathrm{H}=$ Shannon diversity index

$\mathrm{S}=$ Number of spesies

$\mathrm{ni}=$ Number of type into-i in the total sample

$\mathrm{N}=$ Number of individuals all of species

\subsection{Antagonism of Yeast vs C. gloesporioides}

Antagonist test has been done by scratch yeast on PDA in the middle of medium, while $C$. gloesporioides in a cork borrer was placed on the right and left side of yeast with $3 \mathrm{~cm}$ distance. The culture then has been incubated at room temperature for 10 days and observed every single day by measure width of inhibition zone of yeast to $C$. gloesporioides every day. As a control treatment, was grown $C$. gloesporioides alone without yeast (Sugipriatini, 2009). Percentage of rate barriers relative to the pathogen be calculated by the formula:

Annotation :

$$
\mathrm{THR}=\frac{\mathrm{dk}-\mathrm{dp}}{\mathrm{dk}} \times 100 \%
$$

THR = Percentage resitance level relative to the growth og pathogens

$\mathrm{Dk} \quad=$ Number of colonies radius $\left(\mathrm{r}_{1}+\mathrm{r}_{2}\right)$ pathogens without treatment (control)

DP $\quad=$ Number of colonies radius $\left(r_{1}+r_{2}\right)$ pathogens with yeast treatment

\subsection{Potential Use of Yeast in Control of C. gloesporioides on Avocado Fruit}

The avocados soaked on $\mathrm{NaOCl}$ of $1 \%$ for 2 minutes (Zhang et al, 2007). Then it washed 2 times with sterile aquadest and dried. Avocados were sprayed with suspension yeast that containing Tween 80, then the fruits is dried and placed on a plastic tray contained tissue which has been moistened with sterile aquadest. Fruit was inoculated with $50 \mu 1$ suspension $C$. gloesporioides at three points, namely at right, middle, and left edge. Covering with plastic wrap to keep moisture. Incubation for 24 hours in dark condition then move on the condition of not dark for 6 days. Control (no yeast treatment) was prepared as comparison. Observation every 3 day untill day 6 incubation by counting the percentage incidence of the disease. Incidence of disease observed by record the fruits that showing anthracnose symptom each experimental unit. Percentage of incidents disease (KP) be calculated using below formula:

Description :

$$
\mathrm{KP}=\frac{\mathrm{n}}{\mathrm{N}} \times 100 \%
$$

$\mathrm{KP}=$ Incidence of disease

$\mathrm{n} \quad=$ Number of points inoculation that shown symptoms of illness

$\mathrm{N}$ = Number of points of inoculation were observed

\subsection{Data Analysis}

Data from tests antagonist yeast with Colletotrichum gloesporioides will be analysis using analyzed of variance (ANOVA) and continued with LSD test at 5\% level if there is a signicant difference.

\section{RESULTS AND DISCUSSION}

3.1 Isolation and Identification of Colletotrichum gloesporioides 
Isolation of fungi $C$. gloesporioides of avocados that showing anthracnose symptoms then cultured on PDA medium. The macroscopically identification result is a pure culture of $C$. gloesporioides initially colorless white, then the longer changed to colored white yellowing or tends to orange. The texture colonies of thick, dense, and appear to have dots rough colonies. Fungal colonies fill the petridish within 10 days on PDA. According Guarro et al (1998) stated that C. gloesporioides grown on various media such as PDA, cornmeal, maltextract, and oatmeal has colony color ranging from white to grayish, the texture colony has the same characteristics and fulfill the petridish within 10 days.

Microscopic identification show this fungus has insulated hyphae hyaline and has branching. Colored conidia hyaline, not insulated and oval with both ends blunt. Guarro et al (1998) explains that conidia straight, cylindrical, hyaline, blunt in the end, the lenght varies range 6 -26 x 4 - $7 \mu \mathrm{m}$.
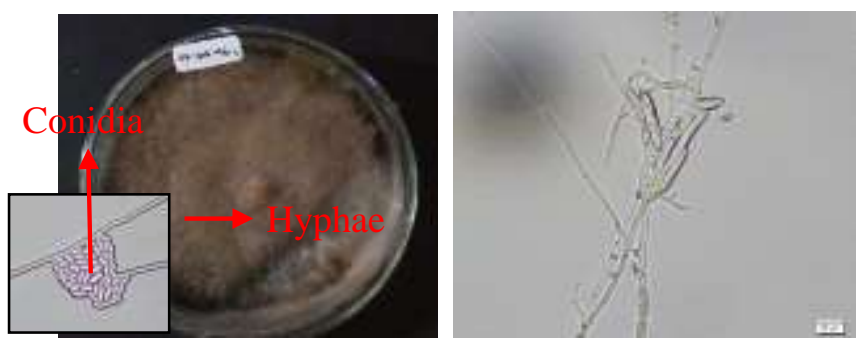

Figure 1. Pathogens C. gloesporioides A. Pure culture of the age of 7 days B. Hyphae dan Conidia

\subsection{Isolation, Identification and Data Analysis of Yeasts}

Isolation of yeast on peel and flesh of green-long avocado and mega gagauan avocad. Based on the results of isolation and identification of yeasts obtained total of 7 isolate are 3 isolates of yeast that isolated from green-long avocado that are Candida sp., Cryptococcus sp., and Filobasidium sp. While on the mega gagauan avocado obtained 4 isolates of yeasts which are Pichia sp, Candida sp. Metschnikowia sp, dan Cryptococcus sp.

The diversity differences of yeast in green-long avocado and mega gagauan avocado obtained using the diversity formula. Isolation results provide the information calculation data with use index diversity (H'). The calculation diversity results presented in Table 2.

Table 2. Calculation of Index Diversity

\begin{tabular}{cccccc}
\hline & & \multicolumn{4}{c}{ Value Index } \\
No. & Avocados & $\mathrm{H}^{\prime}$ & $\Sigma$ & $\Sigma$ & $\Sigma$ \\
Genus & Species & Colony \\
\hline 1 & $\begin{array}{c}\text { Green- } \\
\text { long }\end{array}$ & $\begin{array}{c}6.009 \\
(\text { High) }\end{array}$ & 3 & 3 & 408 \\
2 & $\begin{array}{c}\text { Mega } \\
\text { gagauan }\end{array}$ & $\begin{array}{c}6.422 \\
\text { (High) }\end{array}$ & 4 & 4 & 616 \\
\hline & Total & 12.431 & & 7 & 1024 \\
\hline
\end{tabular}

ISSN Print $\quad: 1979-7141$

ISSN Online : 2541-1942 
Yeast diversity index found in green-long avocado and mega gagauan avocado are include in the high category, because the value that resulted more than 3. However, the yeast diversity index on mega gagauan avocado has greater value is 6.422 , while green-long avocado is 6.009 . The value of yeast diversity index that high can be influenced by internal factors such as nutrient content in avocados. Green-long and mega gagauan avocados contains unlimited carbohydrate and adequate protein, so the yeast preffered grow than other pathogens. According to Widayati (2013), states that have carbohydrate compound making up one of them came from carbon. Microbes are derived from fungus bracket will grow well in environment containing high carbon source as a source of energy that could support metabolism (Sofiana, et al., 2016; Muhibuddin. et al., 2011). While protein is a source of nitrogen for yeast. Nitrogen is requaired for yeast to synthesis protein and nukleit acid. So that the higher source of nutrients available to microbes, the more high number of microbes in a population.

\subsection{Yeast Antagonist Test to Pathogens C. gloesporioides}

Antagonist test conducted against 7 isolates of yeast with pathogen $C$. gloesporioides on PDA medium. Observation inhibition of yeast against the pathogen $C$. gloesporioides performed from 1 DAO to 6 DAO. Percentage of yeast inhibition againts pathogen C. gloesporioides fot 6 DAO are presented in Table 3.

Table 3. Percentage Inhibition of Yeast to growth of $C$. gloesporioides for 6 DAO

\begin{tabular}{lc}
\hline Yeast treatment & Average of Percentage inhibition (\%) \\
\hline Candida sp. 1 & $7.755 \mathrm{a}$ \\
Filobasidium sp. & $11.452 \mathrm{bc}$ \\
Cryptococcus sp. 2 & $14.345 \mathrm{c}$ \\
Pichia sp. & $10.595 \mathrm{ab}$ \\
Candida sp. 2 & $11.807 \mathrm{bc}$ \\
Cryptococcus sp. 2 & $9.717 \mathrm{ab}$ \\
Metschinokowia sp. & $10.723 \mathrm{ab}$ \\
\hline
\end{tabular}

Based on the results LSD test it is known that the highest potential inhibition is in treatment using Cryptococcus sp. of green-long avocado is able to inhibit the growth of $C$. gloesporioides amounted to $14.35 \%$. The antagonist result between pathogen $C$. gloesporioides with 7 yeast isolates indicate that the isolated of yeast have found to have antagonistic interactions with pathogen $C$. gloesporioides. Mechanism antagonist produced by the yeast among others is mechanism of competition and antibiosis.

Competition mechanism shown with growth slowly pathogenic fungal colonies when grown together with yeast at media the same one. It is powered by Morrica and Ragazzi (2008), the indication of the success of the competition through cell growth and colony yeast antagonist that faster or a number of molecule organism result yeast metabolism more compared to fungal pathogens.

Antibiosis mechanism indicated by the clear zone around yeast not overgrown colony pathogen $C$. gloesporioides. Inhibition zone that form allegedly because presence produced by the enzymatic mechanism yeast, happens the food competition, where live competition between yeast with fungus pathogens. This is consistent with the statement Haggag and Mohamed (2007), namely yeast antibiosis mechanism involving use of secondary metabolites such as pelisis enzymes, volatile compounds, siderophores or other toxic compounds which can cause fungistatic, cell wall lysis, or necrotic, so fungal growth is inhibited. Chet and Henis (1975) which says that an enzyme 
produced by the yeast is able to degrade the cell walls of pathogens with stimulate the hydrolysis of chitin content (poli $\beta$ - 1,4 (acetamido - 2-deoxy) - D - glucosida) which is the largest component of the fungal cell wall constituent.

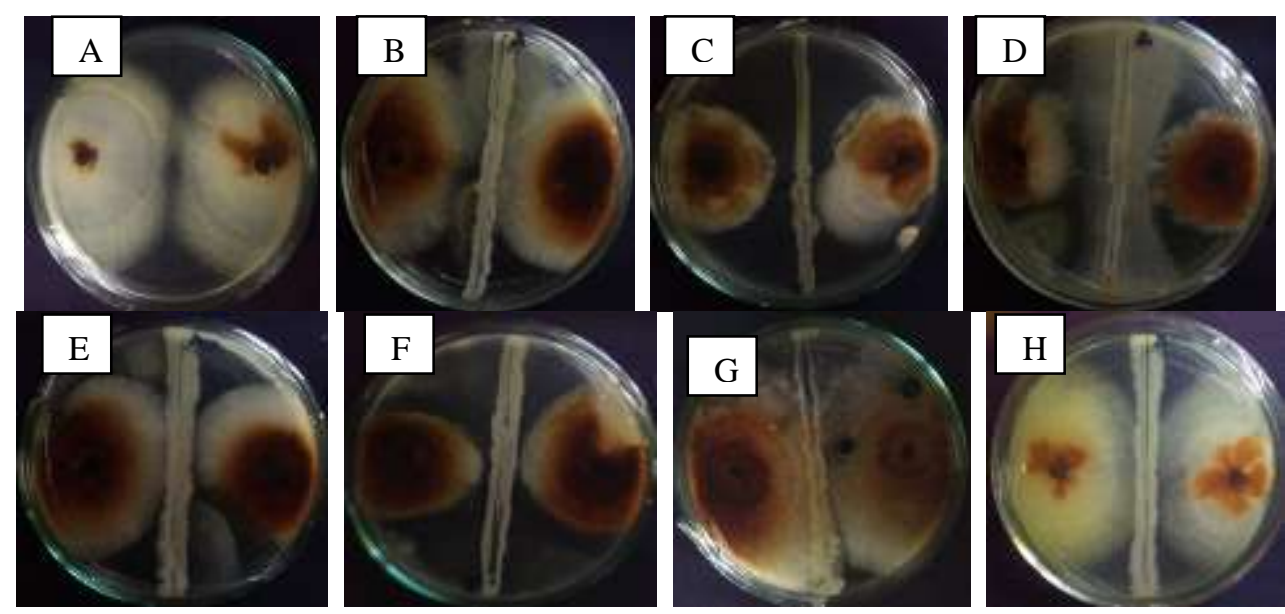

Figure 2. The results of antagonistic yeast to $C$. gloesporioides at 6 DAO. A: control pathogen $C$. gloesporioides, B: treatment of Candida sp. 1, C: treatment of Filobasidium sp., D: treatment of Cryptococcus sp. 1, E: treatment of Pichia sp., F: treatment of Candida sp. 2, G: treatment of Cryptococcus sp. 2, H: treatment of Metschnikowia sp.

\subsection{Potential Use of Yeast in Control of C. gloesporioides on Avocado Fruit}

The antagonists in vivo conducted to determine the value of incidents disease on avocados. Yeast treatment in $C$. gloesporioides control show results did not different to the percentage of incidents disease.

Table 4. The Incidence Disease Rate

\begin{tabular}{lc}
\hline Yeast treatment & Incident disease level (\%) \\
\hline No Yeast Treatment & 83.33 \\
Candida sp. 1 & 83.33 \\
Filobasidium sp. & 83.33 \\
Cryptococcus sp. 1 & 50.00 \\
Pichia sp. & 83.33 \\
Candida sp. 2 & 66.67 \\
Cryptococcus sp. 2 & 66.67 \\
Metschinokowia sp. & 83.33 \\
\hline
\end{tabular}

Avocados are injected with $C$. gloesporioides more brown, so the point of inoculation of pathogenic $C$. gloesporioides less clearly visible because of the color of symptoms $C$. gloesporioides mingle with ripe of avocados. This is happen because the indicator maturity time of

ISSN Print $\quad: 1979-7141$

ISSN Online : 2541-1942 
avocados tested only on appearance fruit that looks a little soft, so when testing the fruits first ripe causing fruits change color became dark and obscure the point of $C$. gloesporioides symptomatic.

Spraying method that applied to avocados able provide opportunities for the yeast to infect avocados, so that suppression of injection $C$. gloesporioides can reduced. Avocados were sprayed with yeast suspension makes the fruits are more resistaning, because the surface is coated by a yeast which able to inhibit pathogen infection. The use of yeast sprayed on the avocados is one form coating fruit with using agents antagonist known biodible coatings. According to Greener and Fennema (1989), the coating fruits can be done with some how are dip application, spray application, foam application, and drip application.

Yeast is applied through spraying the yeast suspension on the avocados are able to produce disease suppression are 50\%. The ability of yeast in pressing the incidence of illness allegedly because yeast able to produce enzyme that potentially inhibit, suppress and stimulating some type of response host defense (Rahmana, et al., 2016; Sastrahidayat, et al., 2011). Paster et al. (1993), states that yeast cell can inhibited fungus poliferation. Backed by a statement Suzzi et al. (1995) which says that the yeast cells in other microbes play a role important in degraging cells and spores of fungus. Others researchers: Kusumaningati dkk., (2013); Kartikasari, dkk., (2013); Muhibuddin, et al. (2016) also state that fermentation ability of yeast as one indication of yeast quality including response of defense.
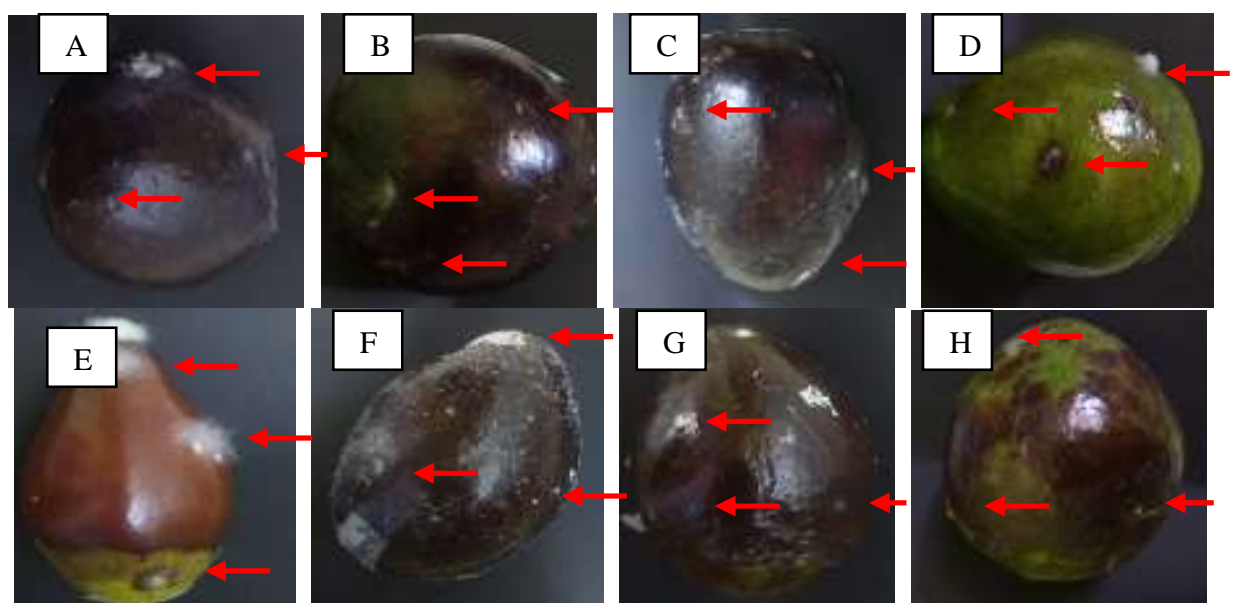

Figure 3. Results of inoculation C. gloesporioides on avocados on 6 days after inoculation. A: no treatment, B: treatment of Candida sp. 1, C: treatment of Filobasidium sp., D: treatment of Cryptococcus sp. 1, E: treatment of Pichia sp., F: treatment of Candida sp. 2, G: treatment of Cryptococcus sp. 2, H: treatment of Metschnikowia sp. Description: red arrow, location who drip C. gloesporioides

\section{CONCLUSION}

Based on the research it can be concluded that yeasts antagonistic can be found on the peel and flesh of mega gagauan avocado and green-long avocado. On green-long avocado, the obtained yeast with the genus is Candida sp., Filobasidum sp., Cryptococcus sp. While mega gagauan avocado, the obtained yeasts with the genus is Pichia sp., Candida sp., Cryptococcus sp. , dan Metschnikowia sp. The value of yeast diversity index mega gagauan avocado and green-long avocado included in the high diversity category. Yeast that could potentially control of $C$. gloeosporioides was Cryptococcus sp. that isolated from green-long avocado. 


\section{SUGGESTION}

Based on the research, there should be more research about testing of metabolic compounds contained by yeast in suppressing the growth of pathogen C. gloesporioides. Mechanism antagonist from yeast in controlling pathogenic C. gloesporioides microscopically, so it can be known the process of control. Examination with extend the observation time on various condition of temperature and environment as a model experiment likened with conditions during the distribution of marketing process.

\section{REFFERENCES}

Assis, S. M. P. and R. L. R. Mariano. 1999. Antagonisme of yeast to Xanthomonas campestris pv. campestris on cabbage phylloplane in field. Rev. Microbiol., Vol. 30: 191-5.

Barnett, H. L. and B. B. Hunter. 1998. Illustrated Marga of Imperfect Fungi. 4th edition. USA: Prentice-Hall, Inc.

Brower, J. E. and J. H. Zar.1977. Field and Laboartory Methods for General Ecology. WM. J. Brown Company Publisher. Dubuque. Iowa.

Chet I, and Y. Henis. 1975. Microbiology control of plant pathogen. Adv. App. Microbiol 19: 85111.

El-tarabily, K. And A. K. Sivacithamparam. 2006. Potential of yeasts as biocontrol agents of soilborne fungal plant pathogens and as plant growth promoters. Mycoscience. Vol 47: 25-35.

Greener I. K., and O. Fennema. 1989. Evaluation of Edible, Bilayer Films for Use as Moisture Barriers for Food. Journal of Food Science. Vol. 54. 6: 1400-1406.

Guarro, J. J. Gene. \& A. M. Stchigel. 1998. Development in Fungal Taxonomy. Clinical Microbiology Reviews, Vol. 12, no. 3: 454-500.

Haggag, W. M., and H. A. A. Mohamed. 2007. Biotechnological aspects of microorganisms used in plant biological control. American-Eurasian J. Of Sustainable Agriculture. 1(1): 7-12.

Ivanesthi I.R, S Nurhatika, A. Muhibuddin, 2016. Potensi Fermentasi Etanol Isolat Yeast Tanah yang Diisolasi dari Kabupaten Jember, Jawa Timur. Jurnal Sains dan Seni ITS 5 (2)

Kartikasari S.D, S Nurhatika, A. Muhibuddin, 2013. Potensi Alang-alang (Imperata cylindrica (L.) Beauv) dalam Produksi Etanol Menggunakan Bakteri Zymomonas mobilis. Jurnal Sains dan Seni ITS 2 (2), E127-E131.

Kurtzman, C. P., and J. W. Fell. 1998. The yeast: A Taxonomic Study, 3rd ed. Elsevier, Amsterdam: xvii + 1035 pp.

Kusumaningati, M.A, S Nurhatika, A. Muhibuddin. 2013. Pengaruh Konsentrasi Inokulum Bakteri Zymomonas mobilis dan Lama Fermentasi Pada Produksi Etanol dari Sampah Sayur dan Buah Pasar Wonokromo Surabaya. Jurnal Sains dan Seni ITS 2 (2), E218E223.

Ludwig, J. A. and J. F. Reynod. 1988. Statistical Ecology: Primer on Methods and Computing. John Wiley and Sons Inc. Canada.

Morrica, S. And A. Ragazzi. 2008. Fungal Endophytes in Mediterranean Oak Forests: a Lesson from Discula quercina. Phytopathology. 98(4): 380-386.

Muhibuddin A, AL Abadi. 2011. Biodiversity of Soil Fungi on Integrated Pest Management Farming System. Agrivita 33 (2), 111.

Muhibuddin, A. 2016. Ethanol Fermentation Potency Of Wild Yeast On Bamboo Rhyzosphere. Journal of Environmental Engineering and Sustainable Technology 3 (2), 121-127.

ISSN Print $\quad: 1979-7141$

ISSN Online : 2541-1942 
Nelson, S. 2008. Antrachnose of Avocado. College of Tropical Agriculture and Human Resource. Mānoa: University of Hawai'i.

Paster, N., S. Drobby., E. Chaluyz., M. Menasherov., R. Ntzan., and C. L. Wilson. 1993. Evaluation of potential of the yeasts Pichia guilliermondil as a biocontrol agent against $A$. falvus and fungi of stored soya beans. Mycol Res. 97(10): 1201-1206.

Rahmana S.F, S Nurhatika, A Muhibuddin. 2016. Uji Potensi Fermentasi Etanol Beberapa Yeast yang Diisolasi dari Daerah Malang, Jawa Timur dengan Metode SDN (Soil Drive Nutrient). Jurnal Sains dan Seni ITS 5 (2)

Sari, D.Y.R, TB Saputro, A Muhibuddin. 2016. Uji Potensi Fermentasi Etanol Yeast Tanah yang Diisolasi dari Metode Budidaya SDN di Daerah Batu, Jawa Timur. Jurnal Sains dan Seni ITS 5 (2).

Shofiana, R.H. L. Sulistyowati, A. Muhibuddin. 2015. Eksplorasi jamur endofit dan khamir pada tanaman cengkeh (Syzygium aromaticum) serta uji potensi antagonismenya terhadap jamur akar putih (Rigidoporus microporus). Jurnal Hama dan Penyakit Tumbuhan 3 (1), pp. 75-83.

Sastrahidayat, I.R. Djauhari, N Saleh, A Muhibuddin. 2011. Control of Damping Off Disease Caused by Sclerotium Rolfsii Sacc. using Actinomycetes and Vam Fungi on Soybean in The Dry Land Based on Microorganism Diversity of Rhizosphere Zone. Agrivita 33 (1), 40.

Sugipriatini, D. 2009. Potensi Penggunaan Khamir dan Kitosan untuk Pengendalian Busuk Buah Lasiodiplodia theobromae (Pat.) Griffon \& Maubl. (syn. Botryodiplodia theobromae Pat.) pada Buah Mangga Selama Penyimpanan (tesis). Sekolah Pascasarjana Institut Pertanian Bogor.

Suzzi G., P. Romano., I. Ponti., and C. Montuschi. 1995. Natural wine yeast as biocontrol agent. J. Appl. Bacteriol. 78: 304-308.

Widayati, E. 2013. Dinamika komunitas mikroba rizosfir dan kontribusinya terhadap pertumbuhan tanaman hutan. Jurnal Tekno Hutan Tanaman. 6 (2): 55-64.

Yarrow, D. 1998. Methods for the Isolation, Mainenance and Identification of Yeast. Dalam Kurtzman, C. P. And J. W. Fell. 1998. The Yeast a Taxonomic Study. 4th edition. Amsterdam: Elsevier.

Zhang, H., X. Zheng., and T. Yu. 2007. Biological Control of Postharvest Diseases of Peach with Cryptococcus laurentii. Food Control. 18: 287-291. 